\title{
A SYSTEM FOR EVALUATING THE DEFORMATION OF VARIOUS MATERIALS UNDER COM- PRESSIVE LOADS
}

R. A. Gallman

\section{MASTER}

UNION CARBIDE
OAK RIDGE Y-12 PLANT

OAK RIDGE, TENNESSEE

prepared for the U.S. ENERGY RESEARCH AND DEVELOPMENT ADMINISTRATION under U.S. GOVERNMENT Contract W-7405 eng 26 


\section{DISCLAIMER}

This report was prepared as an account of work sponsored by an agency of the United States Government. Neither the United States Government nor any agency Thereof, nor any of their employees, makes any warranty, express or implied, or assumes any legal liability or responsibility for the accuracy, completeness, or usefulness of any information, apparatus, product, or process disclosed, or represents that its use would not infringe privately owned rights. Reference herein to any specific commercial product, process, or service by trade name, trademark, manufacturer, or otherwise does not necessarily constitute or imply its endorsement, recommendation, or favoring by the United States Government or any agency thereof. The views and opinions of authors expressed herein do not necessarily state or reflect those of the United States Government or any agency thereof. 


\section{DISCLAIMER}

Portions of this document may be illegible in electronic image products. Images are produced from the best available original document. 


\section{Printed in the United States of America. Available from National Technical Information Service U.S. Department of Commerce 5285 Port Royal Road, Springfield, Virginia 22161 \\ Price: Printed Copy \$4.00; Microfiche \$2.25}

This report was prepared as an account of work sponsored by the United States Government. Neither the United States nor the Energy Research and Development Administration, nor any of their employees, nor any of their contractors, subcontractors, or their employees, makes any warranty, express or implied, or assumes any legal liability or responsibility for the accuracy, completeness or usefulness of any information, apparatus, product or process disclosed, or represents that its use would not infringe privately owned rights. 
Distribution Category: UC-37

\title{
A SYSTEM FOR EVALUATING THE DEFORMATION OF VARIOUS MATERIALS UNDER COMPRESSIVE LOADS
}

\author{
R. A. Gallman \\ Laboratory Development Department \\ Y-12 Development Division
}

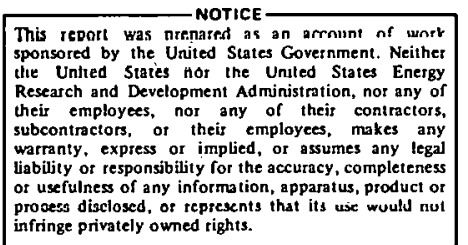

年

infringe privately owned rights.

Oak Ridge $Y-12$ Plant

P. O. Box Y, Oak Ridge, Tennessee 37830

Prepared for the US Energy Research and Development Administration

Under US Government Contract W-7405-eng-26 


\begin{abstract}
A test system has been developed in two versions which can determine the deformation of various materials under selectable, uniaxial, compressive loads. The field model is an inexpensive, rugged, easily operated instrument intended for production use; whereas, the instrumented model is an accurate instrument, with analog and digital outputs, intended for use as a certification tool.
\end{abstract}


CONTENTS

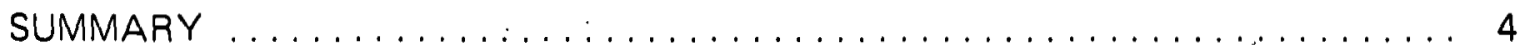

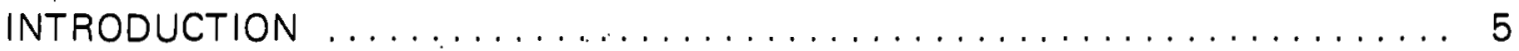

DEFORMATION EVALUATION SYSTEM ...................... 6

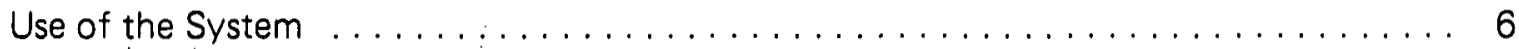

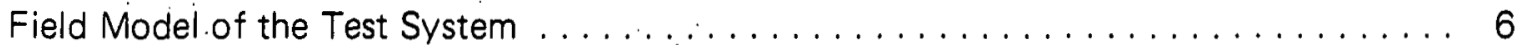

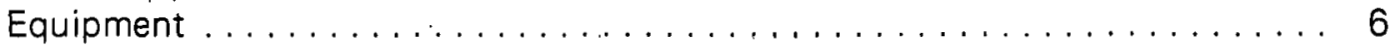

Performance $\ldots \ldots \ldots \ldots \ldots \ldots \ldots \ldots \ldots \ldots \ldots \ldots \ldots \ldots \ldots$

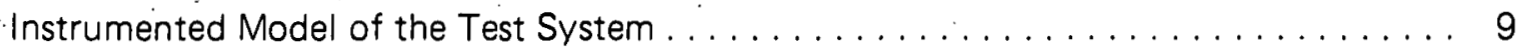

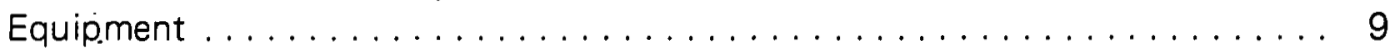

Performance .................................. 9

ACKNOWLEDGEMENTS $\ldots \ldots \ldots \ldots \ldots \ldots \ldots \ldots \ldots \ldots \ldots \ldots$ 


\section{SUMMARY}

A system has been developed which can measure the deformation of various materials under selectable, uniaxial, compressive loads. Two versions of this load-deformation test system are available. The field model is an inexpensive, rugged instrument which is operationally simple and easily transported; the instrumented model is an easily operated instrument which has a high degree of accuracy and is equipped with analog and digital outputs of load and deformation.

The maximum bias and precision (95\% confidence interval) for the field model are 2.0 and $\pm 4.5 \mathrm{~N}$, respectively, on the load and 13.0 and $\pm 14.0 \mu \mathrm{m}$, iespecilively, on the deformation. The maximum bias and precision (95\% confidence interval) of the instrumented model are 0.25 and $\pm 1.0 \mathrm{~N}$, respectively, on the load and 5.0 and $\pm 5.0 \mu \mathrm{m}$, respectively, un the deformation. 


\section{INTRODUCTION}

All substances deform under applied loads. Two phenomena occur when a substance is subjected to such loads: (1) distortion, which is any change in shape, and (2) dilatation, which is any change in density. The summed effect of these two phenomena is called "deformation". Deformation is defined as any change in the configuration of a substance. Experience shows that within the elastic range the relation between deformation and applied stress is linear, being known as Hooke's law. Beyond the elastic range, the material acquires a permanent set which is known as "plastic deformation". The deformation characteristics of a material are significant factors which affect the use of that material and the design of components to be fabricated from that material.

The purpose of this report is to describe a specialized testing system developed to perform deformation studies on various materials under low, uniaxial, compressive loads. The system must satisfy the following criteria: (1) must be inexpensive; (2) must be rugged; (3) must be easily transported; (4) must be simple to operate; (5) must make measurements rapidly; (6) must have a sample pressure range from 14 to $350 \mathrm{kPa}$; (7) must have a 25-mm clearance between the loading platens; (8) the deformation measurement must have sufficient accuracy to make the measurement of value, and (9) the system must be able to accomodate instrumented readout options. The Oak Ridge Y-12 Plant(a) has a need for just such a testing system to study the deformation of various materials under uniaxial, compressive loads. Presently, deformation evaluation of this type requires the use of a universal testing machine, a position gage, and a deflectometer. This sytem has several drawbacks: (1) it is large and expensive; (2) it is a complicated system to operate, requiring a trained technician; (3) a long setup period prior to testing makes it a time-consuming measurement, and (4) the data must be interpreted from load-displacement analog readouts.

(a) Operatcd by the Union Carbide Corporation's Nuclear Division for the US Energy Research and Development Administration. 


\section{DEFORMATION EVALUATION SYSTEM}

\section{USE OF THE SYSTEM}

The load-deformation test system is to be used in two different environments. One environment requires a cheap, rugged instrument which is operationally simple, can be easily transported, and can make rapid measurements. In this situation, a high degree of accuracy on the load and deformation values is not required. These requirements are dictated by production needs for a quick, easy, on-site check of material deformation. The other environment is for a certification test. Here, the system must have variable load capabilities, a high degree of accuracy on the load and deformation values, and analog and digital readouts of load and deformation. These differing requirements indicate a nend for two versions of the load-deformation test system.

\section{FIELD MODEL OF THE TEST SYSTEM}

\section{Equipment}

A view of the field model of the load-deformation test system, which is intended for use in a production area, is presented in Figure 1. To achieve sturdy construction and a low cost, a

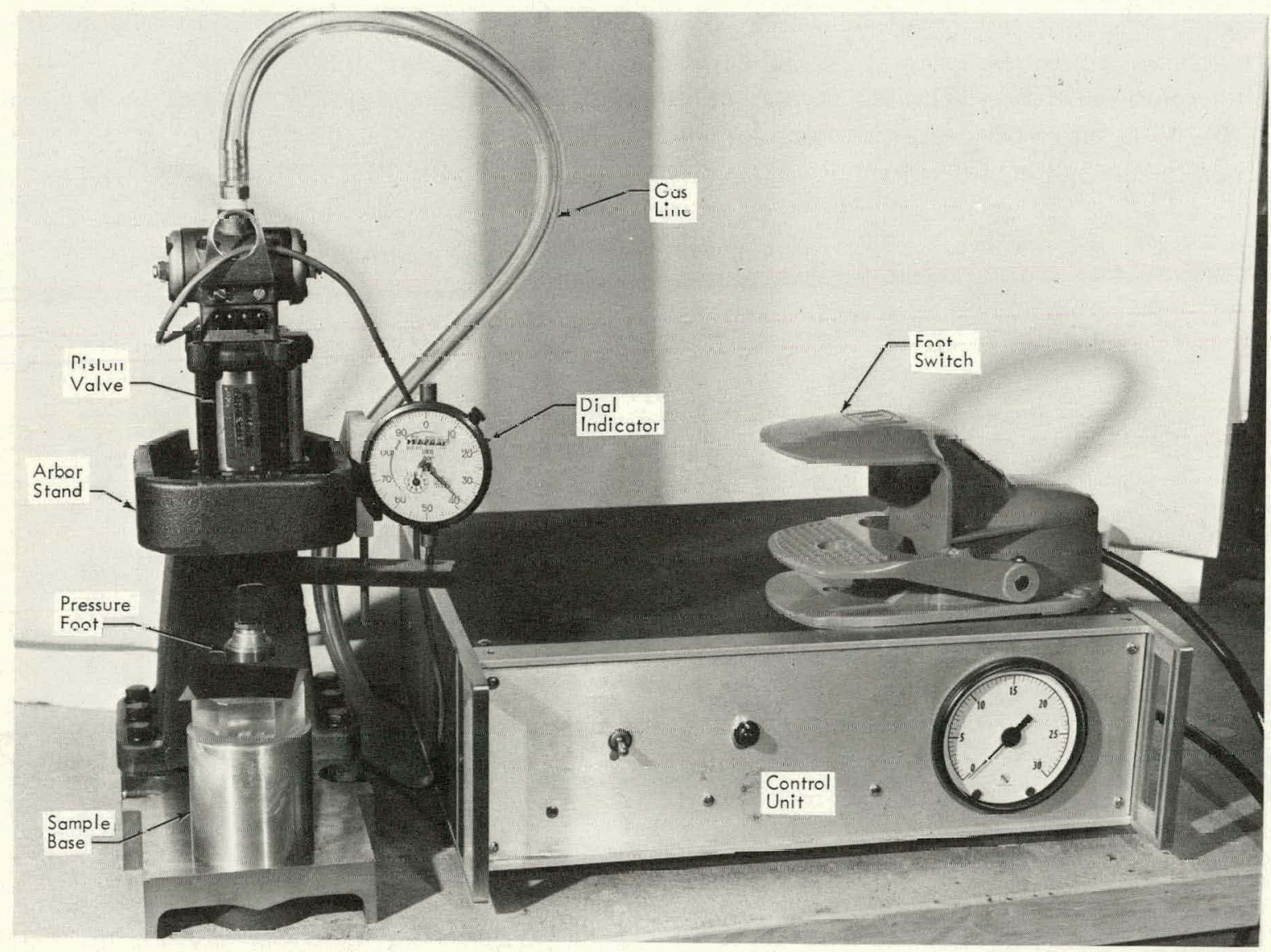

Figure 1. FIELD MODEL OF THE LOAD-DEFORMATION TEST SYSTEM. 
commercial cast arbor stand with a modified base is used as the basic load frame. Attached vertically to the arbor stand is a gas-driven piston with a valve which applies the compressive load. The piston has a $25-\mathrm{mm}$ stroke and is operated by any clean gas supply. Actuation of the piston is accomplished through the control unit which provides power and switching to the piston valve. The load is applied to a sample by a pressure foot attached to the piston. The pressure foot is available in three area sizes $\left(644,1291\right.$, and $\left.2579 \mathrm{~mm}^{2}\right)$ to cover the desired sample pressure range. Smaller pressure feet will allow higher pressures on the sample without increasing the load above $250 \mathrm{~N}$. A 25-mm travel dial indicator is mounted on the arbor stand parallel to the load axis. This instrument indicates movement of the piston via its traveling arm which rides a steel bar attached to the piston. The dial indicator measures liftoff from the sample base. Figure 2 is a block diagram of the field-model test system. The gas regulator adjusts the gas pressure delivered to the piston, thereby regulating the load delivered to the sample; the control unit supplies power to the system and gives an accurate reading of gas pressure; the foot switch actuates the piston. The estimated cost of the field model of the load-deformation test system is $\$ 600$.

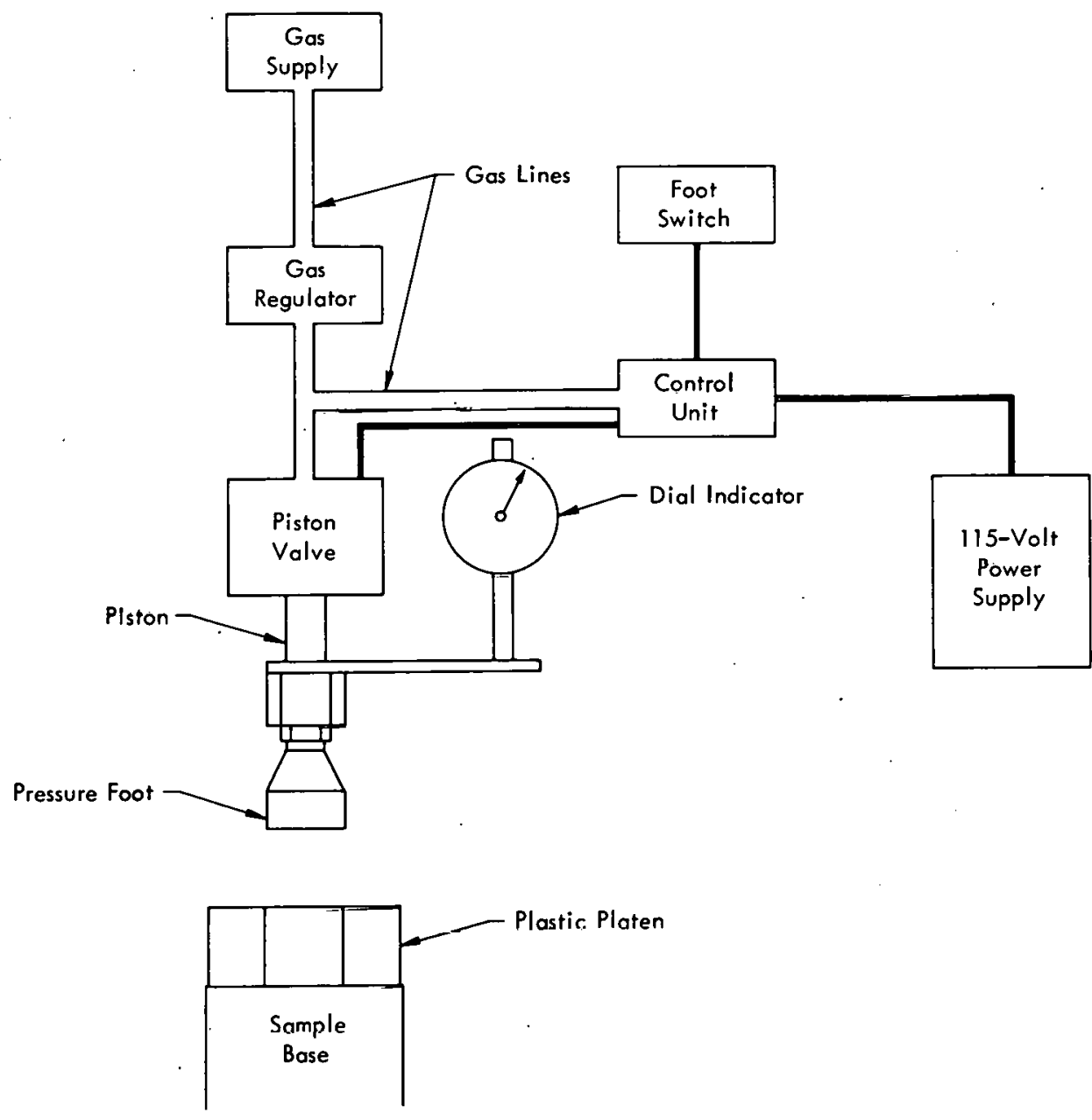

FIgure 2. COMPONENTS OF THE FIEID MODEL OF THE LOAD-DEFORMATION TEST SYSTEM. 
This version of the test system is easy to operate. After applying power by a front panel switch on the control units, the gas regulator is adjusted to deliver the proper gas pressure in order to get the desired load. With the pressure foot seated against the sample base, the dial indicator is adjusted for a zero reading; then the pressure foot is raised, a sample introduced, and the pressure foot lowered. The amount of deformation for a given load and pressure foot (load/pressure foot area equals sample pressure) is found by comparing the dial indicator thickness with the independeritly delermilit, unloaded thicknoss of the same sample.

\section{Performance}

For the field model of the load-deformation test system to be useful, a measurement of the load delıvered by the pistun must be providod. This requirement cidl be met in two ways: (1) use a force gage to measure llie load directly prior to testing while adjusting the gas pressure, or (2) use a predetermined calibration of load as a function of gas pressure. Use of a force gage is preferred because it is a direct measurement and because it is used shortly before testing. However, if such a gage is not available it becomes necessary to have a load/gas pressure calibration. Such a calibration was obtained for this system using a load cell mounted atop the sample base to give load values. The results of this calibration are presented in Table 1 and Figure 3 (the solid line indirates a linear least-squares fit to the data). The maximum bias of the load is dependent upon the measuring technique used, but is generally within two newtons of the known value. Two problems were encountered during testing: (1) there exists a minimum gas pressure $(20 \mathrm{kPa})$ below which the piston cannot be actuated, meaning a minimum load of about $25 \mathrm{~N}$;

Table 1

LOAD VALUEE TO THE PISTON AS, A FUNCTION OF GAS PRESSURE

\begin{tabular}{cc}
\hline $\begin{array}{c}\text { Gas Pressure } \\
(\mathrm{kPa})\end{array}$ & Load Cell Output $(1)$ \\
\hline 138 & 200 \\
131 & 187 \\
124 & 178 \\
117 & 169 \\
110 & 165 \\
103 & 151 \\
96 & 142 \\
90 & 131 \\
83 & 120 \\
76 & 109 \\
89 & 100 \\
62 & 87 \\
55 & 78 \\
48 & 69 \\
41 & 60 \\
34 & 49 \\
28 & 40 \\
24 & 30 \\
21 & 31 \\
\hline
\end{tabular}

(1) Values obtained 15 secunds after piston actuation. (2) during the first 15 seconds after piston actuation, the load decreases by as much as $7 \%$ (lable 2). Thls lime lady i tuidires a minimum delay, after the piston is lowered, ul 11 s seconds bufur taking any rondings. The repeatability of load value was studied also with the result that, for 25 measurements, the $95 \%$ confidence interval amourited to $\pm 4.5 \mathrm{~N}$.

The bias of the dial indicator was studied using thickness standards which wuuld not deform significantly under low loads. Ten thickness values per standard were taken and an average found. These data are presented in Table 3. The maximum bias of the dial indicator was found to be $13.0 \mu \mathrm{m}$. The precision of the dial indicator was studied in a series of tests at three loads. Twenty values were obtained at each load. The standard deviation was found to 
be $7 \mu \mathrm{m}$; hence, a $95 \%$ confidence interval of $\pm 14 \mu \mathrm{m}$. Of the 60 values collected, the maximum difference was $25 \mu \mathrm{m}$.

Table 2

LOAD VALUES TO THE PISTON AS A FUNCTION OF TIME AFTER ACTUATION

\begin{tabular}{ccrcc}
\hline \multirow{2}{*}{$\begin{array}{c}\text { Elapsed } \\
\text { Time } \\
(\mathrm{sec})\end{array}$} & \multicolumn{4}{c}{$\begin{array}{c}\text { Load Cell Output } \\
\text { Gas Pressures (kPa) }\end{array}$} \\
\cline { 2 - 5 } & 34.5 & 69.0 & 103.4 & 137.9 \\
\hline 0 & 50.35 & 102.93 & 151.72 & 207.72 \\
15 & 46.93 & 95.45 & 147.01 & 207.05 \\
30 & 46.53 & 94.03 & 145.85 & 206.03 \\
45 & 46.35 & 93.32 & 145.09 & 205.19 \\
60 & 46.30 & 92.83 & 145.00 & 204.56 \\
75 & 46.21 & 92.52 & 144.38 & 204.16 \\
90 & 46.17 & 92.30 & 144.12 & 203.81 \\
105 & 46.17 & 92.16 & 143.89 & 203.36 \\
120 & 46.13 & 91.98 & 143.67 & 203.18 \\
\hline
\end{tabular}

\section{INSTRUMENTED MODEL OF THE TEST SYSTEM}

\section{Equipment}

The instrumented model of the loaddeformation test system, intended for use as a certification tool, can be seen in Figure 4. The instrumented model is similar to the field model, but with two important differences: (1) a load cell is mounted atop the sample base, replacing the plastic platen seen in Figure 1, and (2) a linear variable differential transformer (LVDT) is mounted on the arbor stand in place of the dial indicator. The load cell has a capacity of

$222.5 \mathrm{~N}$ so that the gas pressure should never be great enough to give a load above this value. A stainless steel disc is attached to its upper surface to serve as a seat for the pressure foot. The LVDT has $25 \mathrm{~mm}$ of travel with a gaging range of $\pm 2.5 \mathrm{~mm}$. Both the LVDT and load cell control units have digital displays as well as analog and digital outputs.

A block diagram of the instrumented model is given in Figure 5. This version of the load-deformation test system is operated similarly to the field model; the only differences are that direct load readings are obtained during the test from the load cell and the LVDT provides the deformation measurement. The same problems of minimum gas pressure to actuate the piston and decreasing load during the first 15 securnds apply to this version. Both readouts can be interfaced to a strip-chart recorder or a computer. The estimated cost of the instrumented model of the load-deformation test system is $\$ 3200$.

\section{Performance}

To develop confidence in the load and thickness values obtained from the instrumented model, the bias and precision of the load cell and the LVDT were determined under normal operating conditiuns and under conditions designed to maximize error and variability.

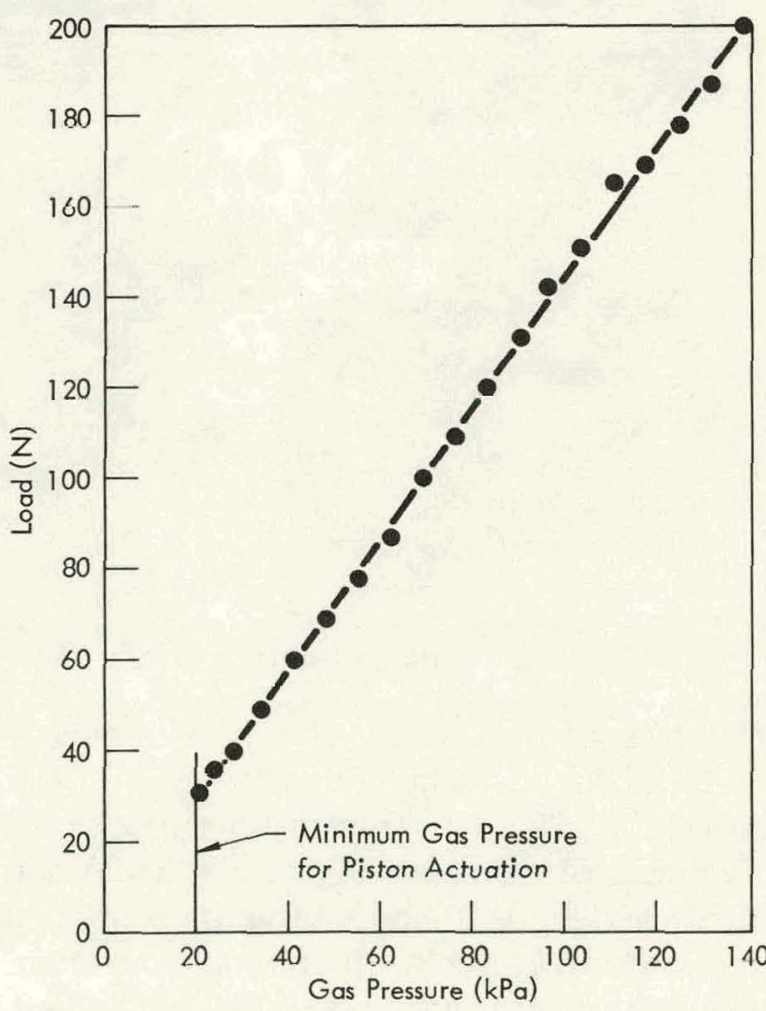

Figure 3. LOAD VALUES TO THE PISTON AS A FUNCTION OF THE GAS PRESSURE. 
Table 3

DIAL INDICATOR BIAS DATA FOR THE FIELD MODEL

\begin{tabular}{|c|c|c|c|c|c|c|c|c|c|c|c|}
\hline \multirow{2}{*}{$\begin{array}{c}\text { Actual } \\
\text { Thickness } \\
(\mu \mathrm{m})\end{array}$} & \multicolumn{11}{|c|}{ Dial Indicator Readings $(\mu \mathrm{m})$} \\
\hline & 1 & 2 & 3 & 4 & 5 & 6 & 7 & 8 & 9 & 10 & $\begin{array}{l}\text { Mean } \\
( \pm 1 \sigma)\end{array}$ \\
\hline 0.0 & 0.0 & 0.0 & 2.5 & 2.5 & 5.0 & 5.0 & 2.5 & 2.5 & 2.5 & 0.0 & $2.5 \pm 2.5$ \\
\hline 127.0 & 127.0 & 127.0 & 124.5 & 127.0 & 127.0 & 132.0 & 127.0 & 127.0 & 129.5 & 127.0 & $127.0 \pm 2.5$ \\
\hline 254.0 & 264.2 & 259.1 & 254.0 & 254.0 & 254.0 & 256.5 & 259.1 & 256.5 & 254.0 & 259.1 & $256.5 \pm 2.5$ \\
\hline 381.0 & 383.5 & 381.0 & 383.5 & 381.0 & 386.1 & 381.0 & 386.1 & 381.0 & 386.1 & 383.5 & $383.5 \pm 2.5$ \\
\hline 508.0 & 510.5 & 497.8 & 502.9 & 497.8 & 500.4 & 505.5 & 500.4 & 502.9 & 500.4 & 502.9 & $502.9 \pm 2.5$ \\
\hline ศ..ร ก & $6.35 n$ & 6.32 .5 & 632,5 & 635.0 & 637.5 & 635.0 & 635.0 & 635.0 & 635.0 & 632.5 & $635.0 \pm 2.5$ \\
\hline 762.0 & 756.9 & 744.2 & 744.2 & 746.8 & 744.2 & 756.9 & 749.3 & 754.4 & 746.8 & 754.4 & $749.3 \pm 5.0$ \\
\hline
\end{tabular}

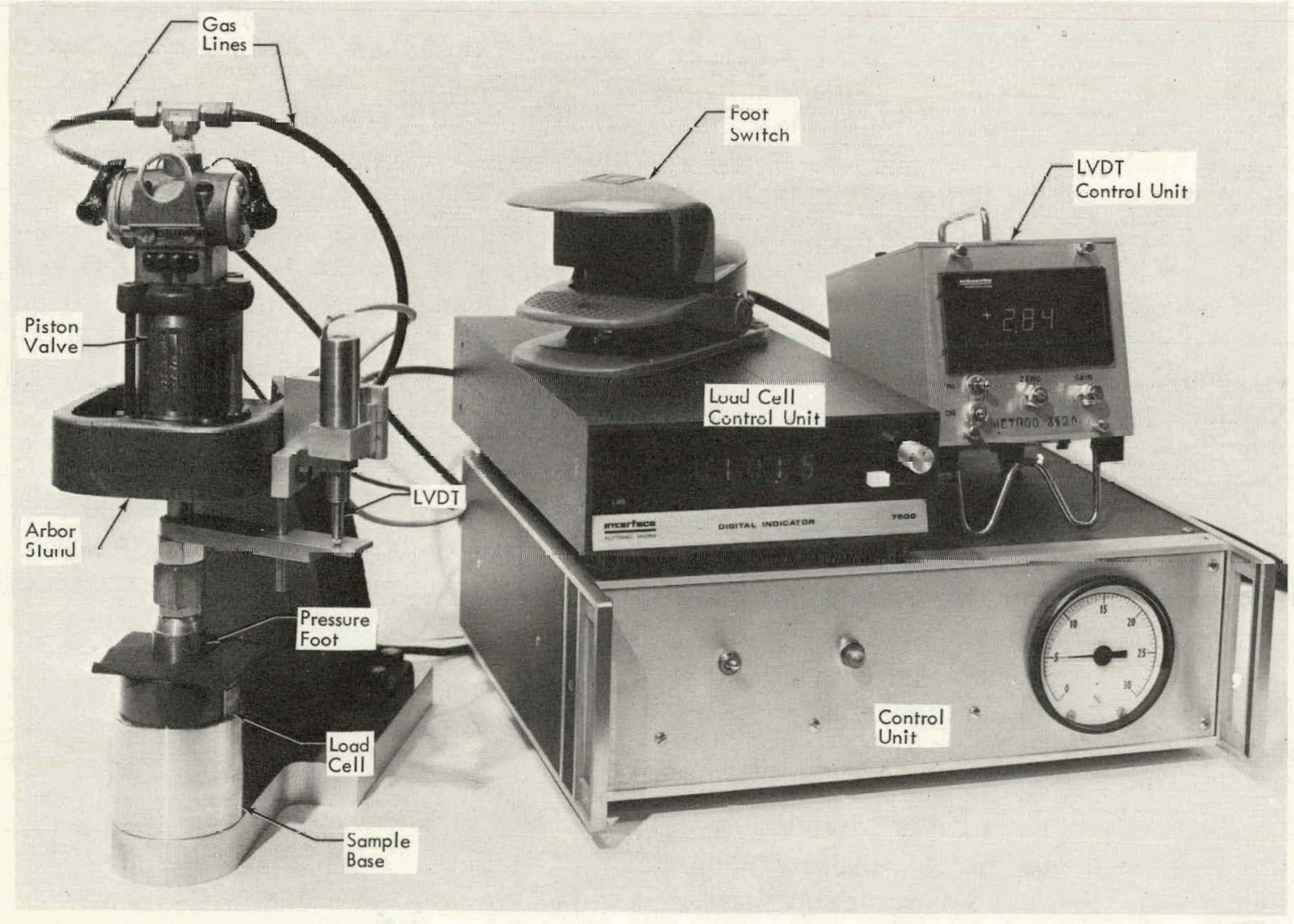

FIgure 4. INSTRUMENTED MODEL OF THE LOAD-DETOIRMAIIUN IESI I SYSTEIMI.

159760

The bias of the load cell was determined using calibrated weights known to $\pm 0.1 \%$ and was found to be within the limit of error of the calibrated weights over its operating range $(0-222.5 \mathrm{~N})$. The load-cell precision was studied at several different gas pressures. Two sets of data were taken, one under normal operating conditions and the other under the adverse operating conditions mentioned earlier. Table 4 lists these results for a gas pressure of $34.5 \mathrm{kPa}$. In normal operation, the difference between the maximum and minimum load values was $1.2 \mathrm{~N}$, with the $95 \%$ confidence interval amounting to $\pm 1.0 \mathrm{~N}$. Under adverse operating conditions, the difference between the maximum and minimum load values was $17.1 \mathrm{~N}$, with the $95 \%$ confidence interval being $\pm 9.8 \mathrm{~N}$. The results were 
similar at the other gas pressures. Also, for a given gas pressure, the load was found to increase as the area of the pressure foot increased, but the increase was always less than $4.5 \mathrm{~N}$. The stability of the load cell was examined over a two-week period and it was found that the output varied no more than $0.1 \mathrm{~N}$.

The bias and precision of the LVDT were determined when used with the instrumented model of the load-deformation test system. The bias of the LVDT alone, separate from the test system, was found to be no more than $2.5 \mu \mathrm{m}$ over its gaging range. It is probably better than that, but the LVDT control unit can be read only to the nearest $2.5 \mu \mathrm{m}$. The bias of the LVDT used in conjunction with the test system was determined using thickness standards that covered its gaging range. Under normal operating conditions, the maximum bias of the LVDT was found to be $5.0 \mu \mathrm{m}$; under adverse operating conditions, it was $15.0 \mu \mathrm{m}$. The precision of the LVDT for a given load was found. Two data sets were generated, one under normal operating conditions and the other under adverse operating conditions. Table 5 summarizes these results for a load of $50.0 \mathrm{~N}$. In normal operation, the

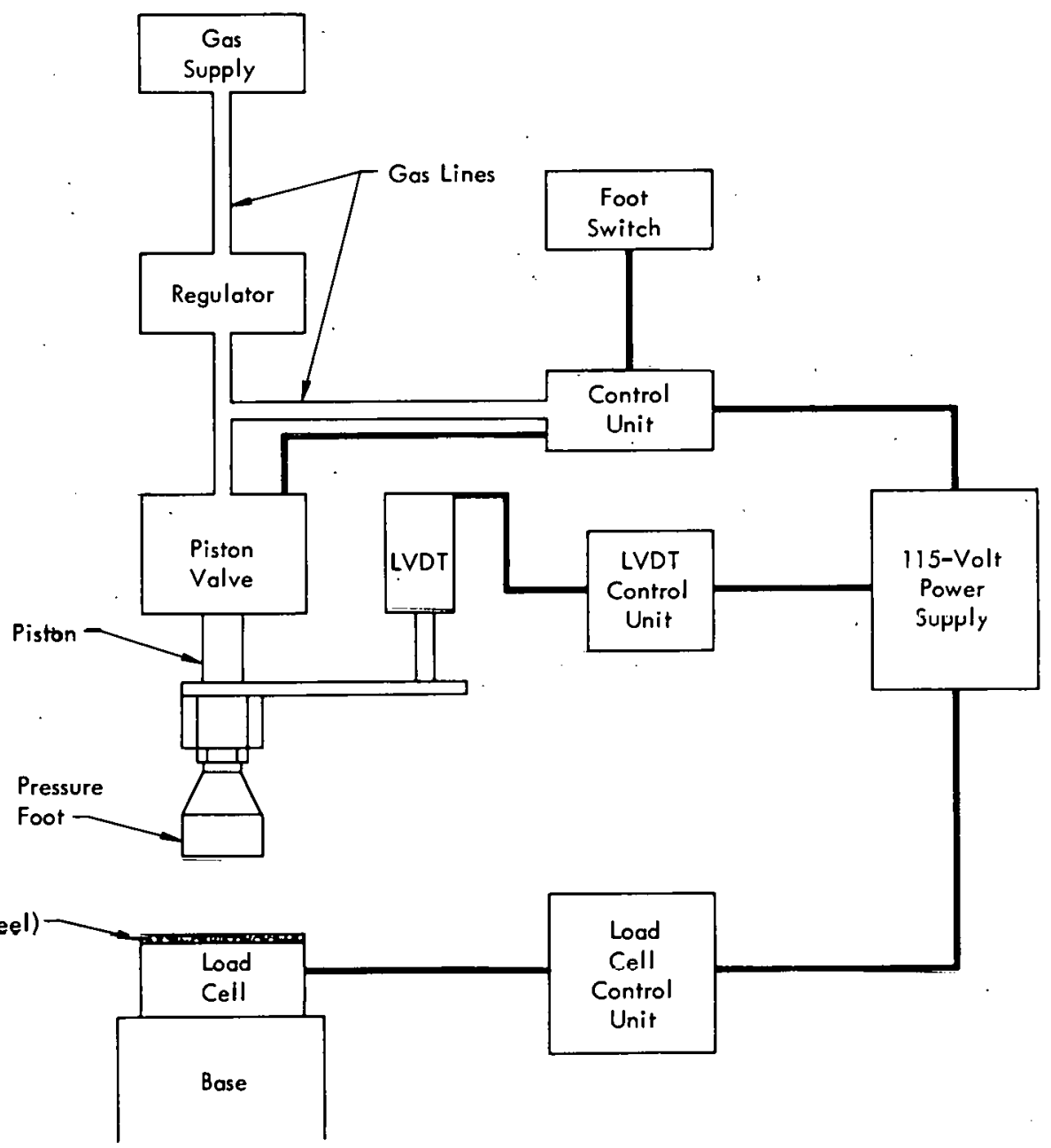

Figure 5. COMPONENTS OF THE INSTRUMENTED MODEI. OF THE LOAD-DEFORMATION TEST SYSTEM. 
Table 4

LOAD CELL REPEATABILITY DATA AT A GAS PRESSURE OF $34.5 \mathrm{kPa}$

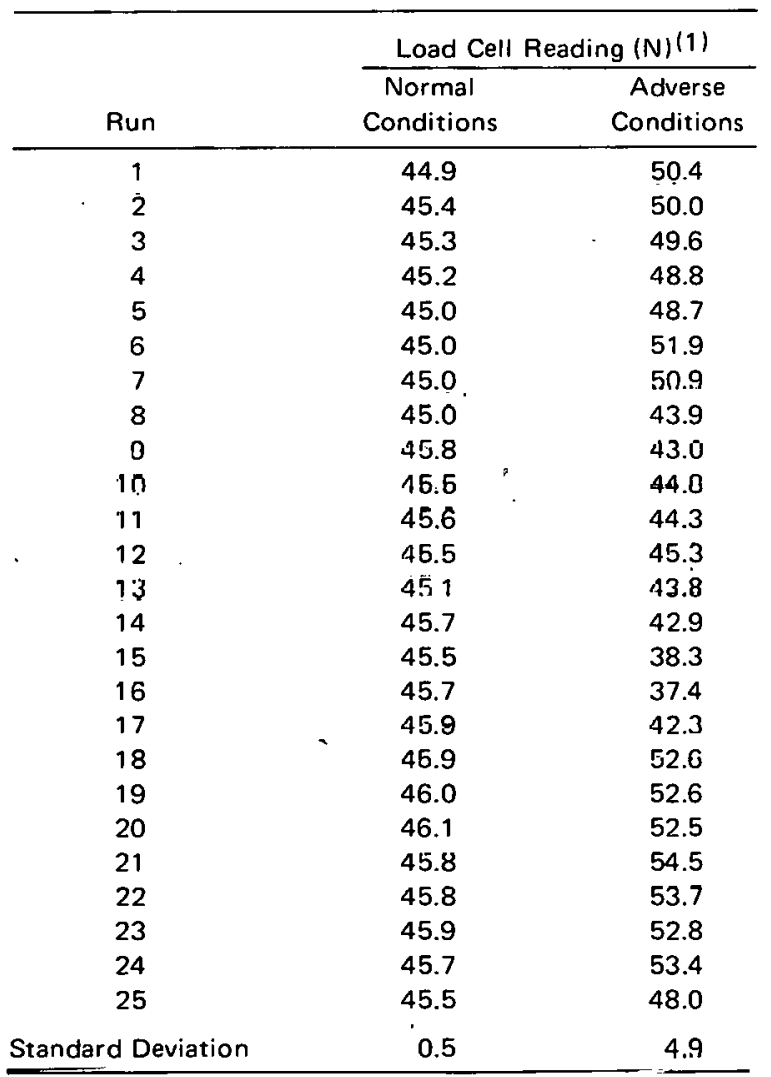

(1) Values obtained about 15 seconds after piston ootuation.
Table 5

LINEAR VARIABLE DIFFERENTIAL TRANSFORMER REPEATABILITY DATA AT A LOAD OF $50.0 \mathrm{~N}$

\begin{tabular}{|c|c|c|}
\hline \multirow[b]{2}{*}{ Run } & \multicolumn{2}{|c|}{ LVDT Reading $(\mu \mathrm{m})$} \\
\hline & $\begin{array}{c}\text { Normal } \\
\text { Conditions }\end{array}$ & $\begin{array}{c}\text { Adverse } \\
\text { Conditions }\end{array}$ \\
\hline 1 & 22.8 & 22.0 \\
\hline 2 & 27.9 & 22.9 \\
\hline 3 & 27.9 & 22.9 \\
\hline 4 & 27.9 & 35.6 \\
\hline 5 & 27.9 & 35.6 \\
\hline 6 & 25.4 & 25.4 \\
\hline 7 & 27.9 & 25.4 \\
\hline 8 & 22.9 & 25.4 \\
\hline 9 & 25.4 & 25.4 \\
\hline 10 & 25.4 & 356 \\
\hline 11 & 22.9 & 22.9 \\
\hline 12 & 22.9 & 22.9 \\
\hline 13 & 25.4 & 22.9 \\
\hline 14 & 27.9 & 22.9 \\
\hline 15 & 25.4 & 22.9 \\
\hline 16 & 25.4 & 38.1 \\
\hline 17 & 25.4 & 38.1 \\
\hline 18 & 25.4 & 33.0 \\
\hline 19 & 25.4 & 35.6 \\
\hline 20 & 22.9 & 38.1 \\
\hline 21 & 30.5 & 22.9 \\
\hline 22 & 27.9 & 22.9 \\
\hline 23 & 27.9 & 22.9 \\
\hline 2,4 & 25.4 & 17.8 \\
\hline 25 & 25.4 & 27.9 \\
\hline Standard Meviation & 2.E & 0.5 \\
\hline
\end{tabular}

difference between the maximum and minimum LVDT readings was $7.6 \mu \mathrm{m}$, with the $95 \%$ confidence interval being $\pm 5.0 \mu \mathrm{m}$. Under adverse operating conditions, the difference between the maximum and minimum LVDT readings was $20.3 \mu \mathrm{m}$, with a $95 \%$ confidence interval of $\pm 13.0 \mu \mathrm{m}$. The stability of the LVDT was studied over a two-week neriod. Results show that its output varied less than $1 \%$. 


\section{ACKNOWLEDGEMENTS}

The author wishes to express his appreciation to various members of the $Y-12$ Development Division for their significant contributions: M. W. Moyer for his suggestion to use an arbor stand as the basic load frame, J. B. Trent for designing the components that converted the arbor stand to a load-deformation test system, J. J. Henry for designing the circuitry in the control unit, and S. A. Wallace for his help in assembling and evaluating the two systems. 


\section{Distribution}

Energy Research and Development Administration - Oak Ridge

Hickman, H. D.

Leed, R. E.

Zachry, D. S, Jr

\section{Oak Ridge Gaseous Diffusion Plant}

Stief, S. S.

Wilcox, W. J., Jr

\section{Oak Ridge $Y 12$ Plant}

Alvey, H. E.

Ardary, Z. L.

Bernander, N. K.

Briscoe. O.W.

Burditt, R. B./Schede, R. W.

Burkhart, L. E.

Ellingson. R. D.

Foulk, D. L.

Froser, R. J.

Gallman, R. A.

Henry, J. J.

Hull, S. G.

Hunter, A. H.

Jackson. V. C.

Juness, F. W.

Kahl, K. G.

Keith $A$.

Kite, H. T.

Long, P. J.

Lundin, M. I.

Mason D. L.

McGinnis, R. S

McLendon, J. D.

Mills. J. M . . Ir

Oliphant, G.W.

Phillips, L. R.

Poore, M. W.

Schreyer, J. M.
Smith, H. F., Jr

Smith, J. H.

Smith, R. D.

Snow, S. G.

Strnner, H. H.

Tewes, W. E.

Trent, J. B.

Weathersby, W. E.

Whitson, W. K.

Yaggi, W. J./Loogin, J. M.

$Y=12$ Central Fileș (b)

$Y$-12 Centrăl Filess (master copy)

$Y-12$ Central Files (route copy)

$Y-12$ Central riles (Y-12RC)

Zerby, C. D.

Paducah Gaseous Diffusion Plant

Levin, R. W.

In addition, this report is distributed in accordance with the category UC-37, Instruments, as given in the USERDA Standard Distribution Lists for Unclassified Scientific and Technical Reports, TID-4500. 